\title{
FORT DES MOINES' 100TH ANNIVERSARY ${ }^{13}$
}

\author{
By Charles H. Grahl
}

Daughters of the American Revolution and the Americans who join with you on this auspicious occasion:

First, as a native of Iowa, who has had the privilege of wearing the uniform of my country in two wars, I want to earnestly commend the Daughters of the American Revolution for its superb service in ever keeping the momentous events of our nation's history before our people. If American citizens of the present should cease to appreciate the sacrifices of the past which have made our blessings possible, we should be unworthy of our precious heritage, and we should be incapable of doing our duty by posterity. The D.A.R. deserves the heartfelt thanks of all loyal Americans for its constant and successful patriotic endeavors.

Iowans, especially those of us who reside near Fort Des Moines, are thrilled by its history. Americans make more of anniversaries than any other people-why we do not know-but we are glad it is so. That characteristic impels us to be stirred deeply by this observance of the 100th birthday of the founding of a fort which has occupied such a conspicuous place in our nation's military annals.

There have been, however, three Forts Des Moines. The establishment which was founded in May 1843 and which we commemorate today was not the first one of that name. The first one was erected in 1834 on the bank of the Mississippi river on what is now the site of Montrose, Iowa, which is a few miles from Keokuk, a city rich in Indian lore and now world famed by the Keokuk dam. That Fort Des Moines was merely a temporary camp, not intended as a permanent military center. It is notable, however, because from there Lieut. Col. Stephen Kearny made a 1,100 miles journey in 1835 through northern Iowa and southern Minnesota and from notes he made wrote his account of "The Iowa District", which gave the name Iowa to the section of Wisconsin territory west of the Mississippi.

Returning from Minnesota, Colonel Kearny and his dragoons camped at the fork of the Raccoon and Des Moines rivers, a location which was even then being considered as a possible site for a new army post. Colonel Kearny disapproved this site because he felt the Indians would resent a military post there and he thought navigation of the Des Moines river too uncertain.

${ }^{13}$ An address by Brig. Gen. Chas. H. Grahl, Iowa Director of Selective Service at the flag-raising ceremonies at the site of Fort Des Moines No. 2 on May 20, 1943. 
The first Fort Des Des Moines was abandoned in 1837, and the site was gradually transformed into the town of Montrose.

Capt. James Allen in the summer of 1842 was sent from Fort Leavenworth to the confluence of the Des Moines and Raccoon rivers with orders to select a site for a new army post. Intermittent war between the Sioux Indians and the Sacs and Foxes, whose principal villages were located on the Des Moines river in what is now Wapello county, made the need for a post acute. Bands of horse thieves and crooked traders, who stole horses from both Indians and white men and profited by selling liquor to the Indians was another reason. Occasional fierce raids by marauding Sioux on the rapidly increasing throng of home-seekers and land speculators from the east added to the need of American soldiers in the area, and the Government was determined to protect the treaty rights of the Indians to the possession of land allotted them for the three years following the Treaty of ' 42 .

Captain Allen, in a letter dated December 30, 1842, wrote the War Department as follows:

"My reason for selecting that point are these: The soil is rich; and wood, stone, water and grass are all at hand. It will be high enough up the river to protect these Indians against the Sioux, and is in the heart of the best part of their new country, where the greatest effort will be made by the squatters to get in. It is about equi-distant from the Missouri and Mississippi rivers and offers a good route to both, the direct route to the Missouri passing around the heads of many ugly branches of the Grand river."

The War Department approved Captain Allen's recommendation and his company of dragoons which had wintered at Fort Sanford, now Agency, Iowa, and a company from Fort Crawford on the Mississippi were designated for garrison duty at the new post.

One historian states that "on the afternoon of May 20,1843, (100 years ago today) Captain Allen with 52 dragoons landed on the point between the two rivers, the Des Moines and the Raccoon, and went into camp on the banks near the edge of the woods."

\section{ORIGINALLY CALLED FORT RACCOON}

Captain Allen's quarters were erected on the site now occupied by the Des Moines, Fort Dodge and Southern Railway station; the quarters of the other officers fronted along Second street. Captain Allen named the new fort Fort Raccoon.

Adjutant General Jones penned a notation before submitting the communication to General Scott: "Fort Iowa would be a very good name, but Raccoon would be shocking; at least in very bad taste."

General Scott informed Captain Allen the name Fort Raccoon was not suitable, and suggested he call it Fort Des Moines until he was otherwise directed. 
Captain Allen didn't like it because he said the new designation would divert mail and supplies to the late post by the name of Fort Des Moines on the Mississippi river, and recommended "some name be given to this post to which this inconvenience may not attach." Eventually, however, Fort Des Moines was accepted.

In the two years after the fort was established the soldiers did a fine service in protecting settlers from vagabonds and hostile Indians. The War Department intended to abandon the post in October 1845. Captain Allen protested, convinced removal of the troops would endanger the lives and property of the law-abiding residents of the sector, but on March 10, 1846, the garrison marched out of the post, and the second Fort Des Moines ceased to exist.

The town of Fort Des Moines was incorporated in 1853 and a year later was made capital of the new state of Iowa. Governor Grimes on January 28, 1857, ended the existence of the town of Fort Des Moines and brought into being the city of Des Moines.

Establishment of a third Fort Des Moines was proposed and defeated in the Fifty-fourth and Fifty-fifth congresses, but was approved by the Fifty-sixth on April 4, 1900.

The War Department on August 5, 1901, reported the United States had acquired title to 400 acres of land about four miles south of Des Moines as a military reservation. The post was formally dedicated on November 12, 1903 . On December 1, 1903, two companies of the Twenty-fifth Infantry, a Negro regiment, took temporary possession of the quarters at the fort. Shortly afterward the first squadron of the Eleventh Cavalry, which had seen service in the Philippines, arrived. They were the first permanent garrison at the post.

From then until the United States was forced into the present world war various regular army outfits were at the fort and it was also the scene of training for Reserve Officers and Citizens Military Training Camps of Iowa. There was no more beautiful army post in America.

\section{First WAAC Training Center}

Fort Des Moines was selected as the first training center for the Women's Army Auxiliary Corps in 1942. To accommodate the thousands of women from all of the states who volunteered the fort was greatly expanded. More than 100 new structural clay-block buildings have been eercted, including 63 barracks, ten mess halls, twenty-one storage and administration buildings, recreation halls, an infirmary and a chapel. Fort Des Moines, through the WAAC, has had probably more publicity than any other military post in the nation.

It is indeed heartening that the Daughters of the American 


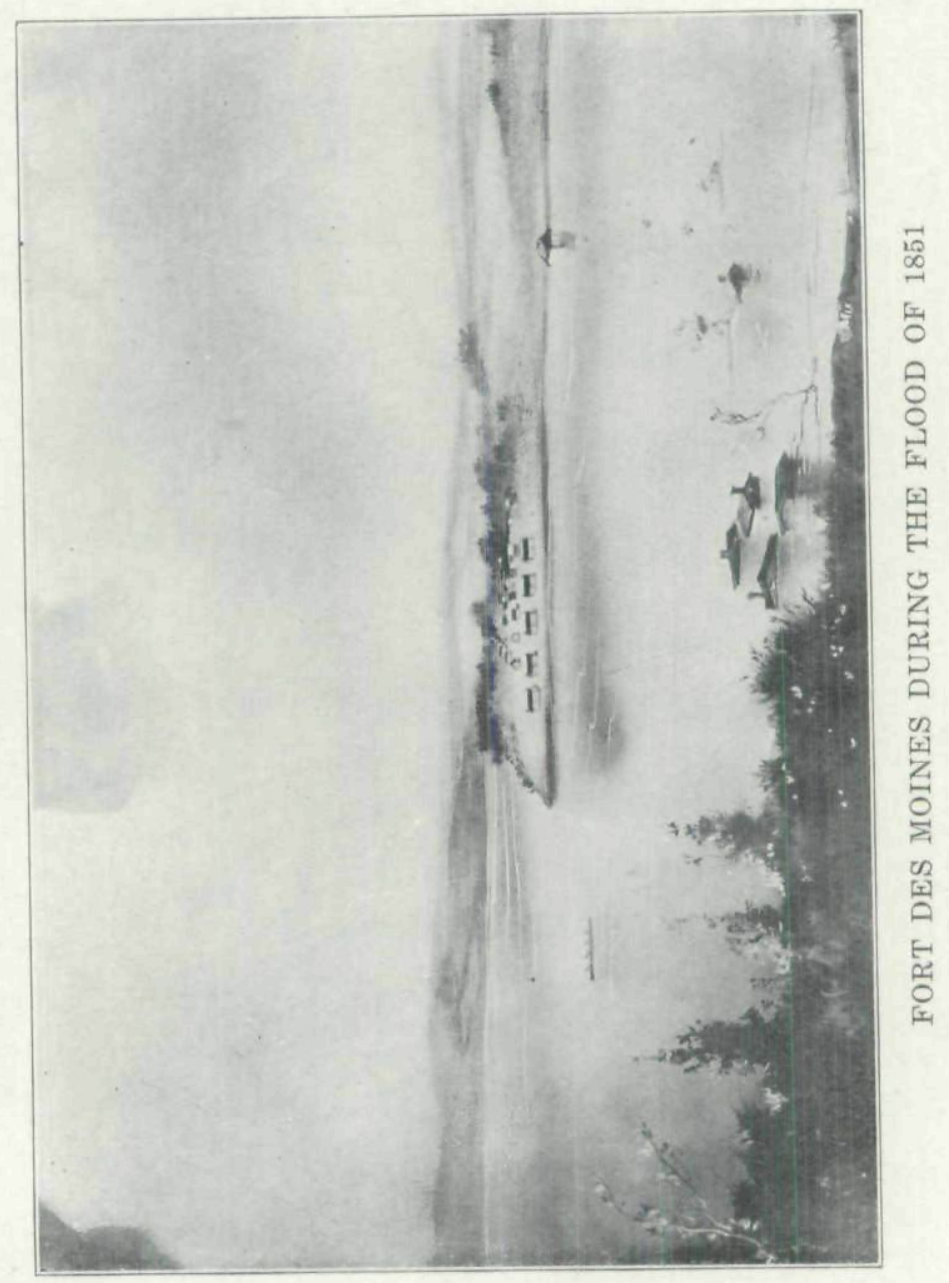


Revolution erected this monument on the site of old Fort Des Moines. Our early landmarks should be preserved and those which have been obliterated should be restored. Our sentiments toward the glories of the past, as we think of how they should ever be held up as inspiration for the future may be summed up in the words: Let us not forget, lest we regret.

It is difficult to imagine that the peaceful scenes amid which we are fortunate to be today might ever be despoiled by enemies, but we are engaged in a war in which there may at any time be stunning surprises. I prophecy nothing, but I would warn you, my listeners, as I wish all other Americans might be warned, that our foes may in some manner bring the conflict to our mainland. If they do, it probably will be from the air. Let us ever keep in mind that in bomber miles over the curves of the earth Iowa is as close as San Francisco to the Aleutian Islands, where the Japanese have bases, and as close as New York is to Norway, which is occupied by the Nazis. Many close students of the tactics of the Axis expect its leaders to do something designed to terrify Americans at home before long. Moreover, every one who knows the situation here is aware of the presence of elements fighting against us through propaganda and ugly rumors.

The second Fort Des Moines was established to enable uniformed men of the nation's armed forces to quell uprisings of enemies within and protect good citizens. They did their arduous, perilous tasks well. Had those men not been here, or had they failed, the whole history of Iowa might have been different and not nearly so bright as it is.

We who are near the site from which those early defenders operated may well be inspired by their zeal and valor, their willingness to give their lives if need be to uphold our government. We should be eager to meet dangers now as they were eager to meet dangers then. We should, in our respective capacities, be just as ready to help save our state and nation as they were to save the sector they were assigned to guard from white renegades and raiding Indians.

When we let the picture of our country, from Bunker Hill to the present, pass before us in our minds' eyes, we see that everything good which has come to the American people came through faith in right and determination to have it at any cost. All that we possess today is ours because our forbears in the thirteen original colonies and in the territories from which our states were formed met the challenges of their times, whether in peace or war.

We who lived in Iowa, I think, are singularly blessed. The pioneers who settled here were of the sturdiest stock of the east from whence they came. The soldiers who were sent here were of the finest of our army. The natural resources which God placed here 
gave abundant opportunity for the settlers to develop the best that was in them, and there was something in the atmosphere of this verdant land which moved them to be thankful to the Creator for everything they had and got.

When I read of Americans, like those who were here a century ago, of their trials, their courage and their achievements, I sometimes wish I might have been one of them. We of the present are often prone to think that the days of adventure and thrills are gone, that there are no new horizons to scale. No doubt the Americans of 1843 thought about the past as we think of their day.

\section{Perils Still Threaten America}

But, if we will face facts, we must realize that 1943 is fraught with more hazards for us and all other Americans than have ever before confronted our people. In place of the renegades and vagabonds of yesterday are criminals constantly increasing the nation's crime record and Fifth Columnists-Japanazis treacherously stabbing us in various ways. The troublesome Indians are gone but glaring at us from beyond our borders are blood-mad Nazis, Japanese and Fascists who want nothing more than to make us slaves on the sacred soil we cherish. Our soldiers are not now fighting enemies here, but they and our sailors are pitted in a life and death struggle against enemies without to save us and our country from conquest, pillage and rapine.

Fort Des Moines a hundred years ago served as an outpost in defense of the constitution and the rights which Americans are guaranteed under it. Today it may well be looked upon as an inpost whose traditions should move all of us to exert our utmost efforts in defense of the principles upon which our democratic form of government is based.

The more we study our America the more we realize the price which has been paid in blood, tears and labor that it might endure - the more we realize that as those who lived before us believed America was worth defending, the more we should strive to live and serve in their spirit. We can pay our debt to our fellow Americans of the past by doing as they did for the Americans of the future.

Here on this hallowed spot, with the life of our nation at stake in the most colossal conflict of all time, I think we might well act today on the words of Woodrow Wilson in 1917, when he said: "But the right is more precious than peace; and we shall fight for the things we have always carried nearest our hearts-for democracy, for the rights of those who submit to authority to have a voice in their own governments, for the rights and liberties of small nations, for the universal dominion of right by such a concert of free peoples as shall bring peace and safety to all nations and make the world itself at last free." 
Copyright of Annals of Iowa is the property of State of Iowa, by \& through the State Historical Society of Iowa and its content may not be copied or emailed to multiple sites or posted to a listserv without the copyright holder's express written permission. However, users may print, download, or email articles for individual use. 